\title{
HUBUNGAN PRAKTIK PEMBERIAN MAKAN BAYI DAN KEJADIAN GASTROENTERITIS
}

\author{
Yuslina FNB Siahaan ",*, Evawany Y Aritonang², Taufik Ashar² \\ ${ }^{1}$ Pasca Sarjana Fakultas Kesehatan Masyarakat USU \\ ${ }^{2}$ Dosen Fakultas Kesehatan Masyarakat Universitas Sumatera Utara \\ *)E-mail: fannybintangshn@gmail.com
}

\begin{abstract}
ABSTRAK
Latar Belakang: Gastroenteritis pada bayi adalah peradangan selaput mukosa lambung dan usus kecil yang ditandai dengan gejala diare, mualmuntah dan demam ringan disertai dengan hilangnya nafsu makan dan rasa tidak nyaman di perut. Pada tahun 2010 gastroenteritis adalah penyebab utama kematian di Indonesia dan berada di urutan pertama sebagai penyebab pasien dirawat di rumah sakit. Tujuan: Menganalisis hubungan praktik pemberian makan bayi dengan kejadian gastroenteritis. Metode: Penelitian ini menggunakan metode case control yang menganalisis hubungan antara pola makan dan kejadian gastroenteritis pada bayi di wilayah kerja Puskesmas Silangit Kabupaten Tapanuli Utara. Sampel dalam penelitian ini adalah bayi berusia 7 hingga 12 bulan sebanyak 94 orang, 47 kasus dan 47 kontrol. Data dianalisis menggunakan uji Chi Square dan Regresi Logistik Berganda. Hasil: Hasil penelitian menunjukkan distribusi pola makan bayi sebagian besar tidak baik sebanyak 78,7\%. Hasil analisis penelitian menunjukkan bahwa ada hubungan yang signifikan antara pola makan dengan kejadian gastroenteritis, dengan nilai $\mathrm{p}<0,001$ dan nilai OR sebesar 8,202. Simpulan: Ibu yang memiliki bayi diberi dorongan untuk memberikan pola makan yang baik kepada bayi dengan cara menyusui secara eksklusif, menerapkan perilaku hidup bersih dan sehat untuk meningkatkan kesehatan bayi.
\end{abstract}

Kata kunci: praktik pemberian makan, gastroenteritis, bayi

\section{The Relationship Between Feeding Practice and the Incidence of Gastroenteritis}

\section{ABSTRACT}

Background: Gastroenteritis in infants is an inflammation of the mucous membrane of the stomach and small intestine characterized by symptoms of diarrhea, nausea, vomiting and mild fever accompanied by loss of appetite and discomfort in the stomach. In 2010 gastroenteritis is the leading cause of death in Indonesia and is the first order that causes patients hospitalized in the hospital. Objective: to analyze the relationship between feeding practice and the incidence of gastroenteritis. Method: This study used a case control method that analyzed the relationship between feeding practice and the incidence of gastroenteritis in infants in the work area of Silangit Public Health Center of North Tapanuli Regency. The sample in this study was 7 to 12 months old infants as many as 94 people, 47 cases and 47 controls. Data were analyzed using Chi Square test and Multiple Logistic Regression. Results: The results showed the distribution of infant feeding practice is mostly not good as much as 78.7\%. The result of research analysis showed that there was a significant correlation between feeding pattern with the incidence of gastroenteritis with $p$ value $<0.001$ and OR value of 8,202. Conclusion: Mothers with babies are encouraged to provide good feeding practice to infants by exclusive breastfeeding, applying clean and healthy living behaviors to improve infant health.

Keywords: Feeding practice, gastroenteritis, infants

\section{LATAR BELAKANG}

Salah satu faktor eksternal yang memengaruhi kejadian gastroenteritis pada bayi antara lain praktik pemberian makan dan higiene sanitasi perorangan.
Praktik pemberian makan pada bayi pada umumnya dipengaruhi oleh ibu sebagai pengasuh utama bayi seperti memberikan ASI dan MP-ASI, memandikan, memakaikan pakaian, dan mengawasi aktivitas 
bayi. Praktek pemberian makanan yang memadai sangat penting untuk tumbuh kembang dan daya tahan tubuh bayi terhadap berbagai serangan penyakit infeksi seperti gastroenteritis (Yanthi, 2001).

Praktik pemberian makan pada bayi seperti pemberian ASI Eksklusif menjadi salah satu upaya untuk memenuhi kebutuhan nutrisi bayi yang mendukung tumbuh kembangnya. Pemberian ASI yang maksimal akan melindungi bayi dari berbagai macam infeksi, baik yang disebabkan oleh bakteri, virus, dan antigen lainnya (Khairuniyah, 2012).

Di Kabupaten Tapanuli Utara dijumpai kasus gastroenteritis yang menyebabkan diare pada bayi 0-1 tahun sebanyak 658 kasus. Sekitar $12,25 \%$ dari total kasus adalah diare. Di Puskesmas Silangit sendiri jumlah penderita gastroenteritis pada bayi usia 0-1 tahun sebanyak 168 kasus, padahal puskesmas ini merupakan puskesmas dengan cakupan ASI eksklusif tertinggi di Kabupaten Tapanuli Utara.

Praktik pemberian makan yang tidak baik pada bayi dapat menimbulkan kejadian penyakit, untuk itu perlu dilakukan analisis hubungan praktik pemberian makan bayi dengan kejadian gastroenteritis.

\section{METODE}

Jenis penelitian yang digunakan adalah penelitian observasional dengan menggunakan desain case control. Sampel pada penelitian ini adalah ibu yang memiliki bayi berusia 7-12 bulan yang didiagnosis Gastroenteritis dan tidak Gastroenteritis di Puskesmas Silangit Kabupaten Tapanuli Utara. Responden untuk kelompok kasus dan kontrol masing-masing 47 orang. Kriteria inklusi untuk sampel kasus adalah bayi berusia 7-12 bulan yang pada bulan Juli s/d September 2017 menderita
Gastroenteritis yang datang dan berobat ke Puskesmas Silangit yang diklasifikasi oleh dokter, perawat yang bertugas dan berdomisili di wilayah kerja Puskesmas Silangit. Sedangkan kriteria inklusi untuk sampel kontrol adalah bayi berusia 7-12 bulan pada bulan Juli s/d September 2017 yang dalam tiga bulan terakhir tidak menderita Gastroenteritis yang datang dan berobat ke Puskesmas Silangit yang diklasifikasi oleh dokter, perawat, berdomisili di wilayah kerja puskesmas Silangit. Pengumpulan data primer dilakukan dengan wawancara langsung kepada responden berpedoman pada kuesioner.

Kuesioner dibuat dengan pertanyaan terutup (ya atau tidak) sebanyak 25 pertanyaan yang berisi praktik pemberian makan bayi (meme), pemberian ASI Eksklusif, cara dan perilaku dalam pengolahan dan pengelolaan makanan bayi. Untuk data sekunder diperoleh dari pencatatan dan dokumen yang ada di Puskesmas Silangit Kabupaten Tapanuli Utara. Pengambilan data dilakukan pada bulan Juli s/d September 2017.

Analisis data secara univariat dilakukan untuk mendapatkan gambaran distribusi frekuensi responden. Analisis ini digunakan untuk memperoleh gambaran pada masingmasing variabel independen yang meliputi karakteristik umur, jenis kelamin, status gizi, imunisasi, ASI Eksklusif, pola asuh (asuh makan, asuh diri, asuh kesehatan). Variabel dependen yaitu gastroenteritis. Untuk mengetahui adanya hubungan praktik pemberian makan terhadap Gastroentetitis dilakukan analisis bivariat dengan menggunakan uji chi square. Izin penelitian didapatkan dari Puskesmas Silangit dan Dinas Kesehatan Kabupaten Tapanuli Utara. 
HASIL

\section{Karakteristik responden}

Tabel 1. Distribusi responden berdasarkan umur, pendidikan dan pekerjaan

di Puskesmas Silangit bulan Juni s/d

September 2017 ( $\mathrm{k}$ kasus $=47$ dan $\mathrm{n}$ kontrol $=47$ )

\begin{tabular}{lcccc}
\hline $\begin{array}{c}\text { Karakteristik } \\
\text { ibu }\end{array}$ & \multicolumn{2}{c}{$\begin{array}{c}\text { Kasus } \\
(\mathbf{n = 4 7 )}\end{array}$} & \multicolumn{2}{c}{$\begin{array}{c}\text { Kontrol } \\
(\mathbf{n}=\mathbf{4 7})\end{array}$} \\
\cline { 2 - 6 } Umur ibu & $\mathrm{n}$ & $\%$ & $\mathrm{n}$ & $\%$ \\
$<20-25$ tahun & 5 & 10,63 & 14 & 29,78 \\
26-30 tahun & 16 & 34,04 & 12 & 25,53 \\
31-35 tahun & 18 & 38,29 & 13 & 27,65 \\
36-40 tahun & 6 & 12,76 & 6 & 12,76 \\
$>40$ tahun & 2 & 4,25 & 2 & 4,25 \\
\hline
\end{tabular}

Pendidikan ibu

\begin{tabular}{lcccc} 
SD & 6 & 12,8 & 2 & 4,3 \\
SMP & 3 & 6,4 & 0 & 0 \\
SMA & 30 & 63,8 & 26 & 55,3 \\
PT & 7 & 14,9 & 19 & 40,4 \\
\hline
\end{tabular}

Pekerjaan ibu

\begin{tabular}{lcccc} 
Petani & 35 & 74,5 & 17 & 36,2 \\
PNS & 4 & 8,5 & 6 & 12,8 \\
Pegawai swasta & 0 & 0 & 5 & 10,6 \\
$\begin{array}{l}\text { Wiraswasta } \\
\begin{array}{l}\text { IRT / Tidak } \\
\text { bekerja }\end{array}\end{array}$ & 5 & 10,6 & 10 & 21,3 \\
\hline
\end{tabular}

Berdasarkan hasil penelitian didapatkan sebagian besar responden pada kasus berumur 31-35 tahun sebanyak 18 orang $(38,29 \%)$ dan paling sedikit berumur $>40$ tahun sebanyak 2 orang $(4,25 \%)$, sedangkan untuk responden pada kontrol distribusi umurnya hampir merata yang meskipun sebagian besar berumur $<20-25$ tahun sebanyak 14 orang $(29,78 \%)$ dan paling sedikit berumur $>40$ tahun sebanyak 2 orang $(4,25 \%)$. Sebagian besar responden pada kasus berpendidikan SMA sebanyak 30 orang $(63,8 \%)$ dan pada kontrol juga sebagian besar memiliki pendidikan SMA sebanyak 26 orang $(55,3 \%)$. Sebagian besar responden memiliki pekerjaan sebagai petani dengan rincian pada kasus sebanyak 35 orang $(74,5 \%)$ dan pada kontrol sebanyak 17 orang $(36,2 \%)$.

Tabel 2. Distribusi bayi berdasarkan umur, jenis kelamin, ASI Ekskslusif di Puskesmas

Silangit bulan Juni s/d September 2017 ( $\mathrm{k}$ kasus=47 dan $\mathrm{n}$ kontrol=47)

\begin{tabular}{|c|c|c|c|c|}
\hline \multirow{2}{*}{$\begin{array}{l}\text { Karakteristik } \\
\text { bayi }\end{array}$} & \multicolumn{2}{|c|}{$\begin{array}{l}\text { Kasus } \\
(n=47)\end{array}$} & \multicolumn{2}{|c|}{$\begin{array}{c}\text { Kontrol } \\
(n=47)\end{array}$} \\
\hline & $n$ & $\%$ & $n$ & $\%$ \\
\hline 7-9 bulan & 22 & 46,8 & 22 & 46,8 \\
\hline 10-12 bulan & 25 & 53,2 & 25 & 53,2 \\
\hline \multicolumn{5}{|l|}{ Jenis kelamin } \\
\hline Laki-laki & 33 & 70,2 & 25 & 53,2 \\
\hline Perempuan & 14 & 29,8 & 22 & 46,8 \\
\hline \multicolumn{5}{|l|}{ ASI Eksklusif } \\
\hline Tidak & 20 & 42,6 & 10 & 21,3 \\
\hline Ya & 27 & 57,4 & 37 & 78,7 \\
\hline
\end{tabular}

Berdasarkan hasil penelitian yang tergambar di tabel 2 didapatkan bahwa sebagian besar responden berumur 10-12 bulan baik pada kasus maupun kontrol yaitu masing-masing sebanyak 25 orang $(53,2 \%)$. Sebagian besar responden berjenis kelamin laki-laki baik pada kelompok kasus yaitu 33 orang $(70,2 \%)$ maupun kontrol sebanyak 25 orang $(53,2 \%)$. Sebagian responden pada kasus dan kontrol memperoleh ASI Eksklusif dengan rincian pada kasus sebanyak 27 orang $(57,4 \%)$ dan pada kontrol sebanyak 37 orang $(78,7 \%)$. 
Tabel 3. Distribusi praktik pemberian makan bayi berdasarkan jawaban responden pada kuesioner di Puskesmas Silangit bulan Juni s/d September 2017 dengan ( $n$ kasus $=47$ dan $n$ kontrol=47)

\begin{tabular}{|c|c|c|c|c|c|c|c|c|c|}
\hline \multirow{3}{*}{ No } & \multirow{3}{*}{ Praktik pemberian makan } & \multicolumn{4}{|c|}{ Kasus } & \multicolumn{4}{|c|}{ Kontrol } \\
\hline & & \multicolumn{2}{|c|}{ Ya } & \multicolumn{2}{|c|}{ Tidak } & \multicolumn{2}{|c|}{ Ya } & \multicolumn{2}{|c|}{ Tidak } \\
\hline & & $\mathbf{n}$ & $\%$ & $\mathbf{n}$ & $\%$ & $\mathbf{n}$ & $\%$ & $\mathbf{n}$ & $\%$ \\
\hline 1 & Bayi ibu mendapat ASI Eksklusif & 27 & 57,4 & 20 & 42,6 & 37 & 78,7 & 10 & 21,3 \\
\hline 2 & $\begin{array}{l}\text { ASI pertama yang keluar yang } \\
\text { berwarna kekuningan diberikan pada } \\
\text { bayi }\end{array}$ & 12 & 25,5 & 35 & 74,5 & 25 & 53,2 & 22 & 46,8 \\
\hline 3 & $\begin{array}{l}\text { Ibu menyusui bayi sampai bayi puas } \\
\text { dan berhenti menyusu }\end{array}$ & 19 & 40,4 & 28 & 59,6 & 21 & 44,7 & 26 & 55,3 \\
\hline 4 & Ibu memberi ASI sesering mungkin & 16 & 34,0 & 31 & 66,0 & 20 & 42,6 & 27 & 57,4 \\
\hline 5 & Ibu memberi bayi susu formula & 25 & 53,2 & 12 & 25,5 & 10 & 21,3 & 37 & 78,8 \\
\hline 6 & Ibu memberi makan bayi 3 kali sehari & 42 & 89,4 & 5 & 10,6 & 47 & 100,0 & 0 & 0,0 \\
\hline 7 & Pemberian ASI kepada bayi terjadwal & 2 & 4,3 & 45 & 95,7 & 26 & 55,3 & 21 & 44,7 \\
\hline 8 & $\begin{array}{l}\text { Ibu memberikan makanan selingan } \\
\text { kepada bayi }\end{array}$ & 39 & 83,0 & 8 & 17,0 & 35 & 74,5 & 12 & 25,5 \\
\hline 9 & $\begin{array}{l}\text { Makanan yang diberikan kepada bayi } \\
\text { dikunyahkan oleh ibu (meme) }\end{array}$ & 36 & 76,6 & 11 & 23,4 & 12 & 25,5 & 35 & 74,5 \\
\hline 10 & $\begin{array}{l}\text { Makanan yang diberikan diolah sendiri } \\
\text { oleh ibu }\end{array}$ & 39 & 83,0 & 8 & 17,0 & 43 & 91,5 & 4 & 8,5 \\
\hline 11 & $\begin{array}{l}\text { Air minum bayi dimasak sampai } \\
\text { mendidih }\end{array}$ & 19 & 40,4 & 28 & 59,6 & 29 & 69,7 & 18 & 38,3 \\
\hline 12 & Makanan bayi dipanaskan kembali & 37 & 78,7 & 10 & 21,3 & 22 & 46,8 & 25 & 53,2 \\
\hline 13 & Bayi diberi makanan orang dewasa & 26 & 55,3 & 21 & 44,7 & 17 & 36,2 & 30 & 63,8 \\
\hline 14 & $\begin{array}{l}\text { Bahan makanan yang digunakan untuk } \\
\text { bayi berbahan segar }\end{array}$ & 23 & 48,9 & 24 & 51,1 & 28 & 59,6 & 19 & 40,4 \\
\hline 15 & Makanan disimpan di wadah tertutup & 47 & 100,0 & 0 & 0,0 & 47 & 100,0 & 0 & 0,0 \\
\hline 16 & Bayi disuap dengan tangan & 32 & 68,1 & 15 & 31,9 & 21 & 44,7 & 26 & 55,3 \\
\hline 17 & $\begin{array}{l}\text { Makanan untuk bayi dimasak secara } \\
\text { khusus }\end{array}$ & 6 & 12,8 & 41 & 87,2 & 19 & 40,4 & 28 & 59,6 \\
\hline 18 & Makanan bayi diberi penyedap rasa & 22 & 46,8 & 25 & 53,2 & 15 & 31,9 & 32 & 68,1 \\
\hline 19 & $\begin{array}{l}\text { Makanan yang akan diolah dicuci } \\
\text { dengan air mengalir }\end{array}$ & 9 & 19,1 & 38 & 80,9 & 21 & 44,7 & 26 & 55,3 \\
\hline 20 & $\begin{array}{l}\text { Sebelum memberi makan bayi, ibu } \\
\text { selalu mencuci tangan }\end{array}$ & 24 & 51,1 & 23 & 48,9 & 31 & 66,0 & 16 & 34,0 \\
\hline
\end{tabular}


Hasil pengukuran pertanyaan praktik pemberian makan bayi didapatkan pada bayi dengan Gastroenteritis sebagian besar tidak mendapat kolostrum sebanyak 35 orang $(74,5 \%)$, mendapat susu formula sebanyak 25 orang $(53,2 \%)$, dimeme sebanyak 36 orang $(76,6 \%)$, air minum tidak dimasak sampai mendidih sebanyak 28 orang $(59,6 \%)$, makanan dipanaskan berulang sebanyak 37 orang $(78,7 \%)$, disuap dengan tangan sebanyak 32 orang $(68,1 \%)$ dan ibu tidak mencuci tangan sebelum memberi makan bayi sebanyak 24 orang $(51,1 \%)$.

Tabel 4. Hubungan praktik pemberian makan bayi dengan kejadian gastroenteritis di Puskesmas Silangit bulan Juni s/d September 2017

\begin{tabular}{lccccc}
\hline & \multicolumn{4}{c}{ Gastroenteritis } & \\
\cline { 2 - 5 } Praktik & \multicolumn{2}{c}{ Tidak } & \multicolumn{2}{c}{ Ya } & Nilai $p$ \\
\cline { 2 - 5 } $\begin{array}{l}\text { pemberian } \\
\text { makan }\end{array}$ & $\mathrm{n}$ & $\%$ & $\mathrm{n}$ & $\%$ & \\
\hline Baik & 29 & 74,4 & 10 & 25,6 & 0,001 \\
Tidak baik & 18 & 32,7 & 37 & 67,7 & \\
\hline
\end{tabular}

Berdasarkan hasil tabulasi silang diperoleh bahwa dari 47 bayi yang mengalami gastroenteritis, terdapat 37 bayi $(67,7 \%)$ yang praktik pemberian makannya tidak baik. Hasil uji chi square dengan nilai $p 0,001<0,05$, artinya ada hubungan ynag bermakna antara praktik pemberian makan dengan kejadian gastroenteritis. Dari hasil uji multivariat dengan menggunakan regresi logistik dengan metode backward stepwise diperoleh nilai OR sebesar 8,202 ( Cl 95\% 2,557-26,311), artinya bayi yang praktik pemberian makannya tidak baik memiliki resiko 8,2 kali mengalami Gastroenteritis dibandingkan dengan yang praktik pemberian makannya baik.

\section{DISKUSI}

Pada penelitian ini, sebagian besar responden berumur 10-12 bulan baik pada kasus maupun kontrol yaitu masing-masing sebanyak 25 orang $(53,2 \%)$. Pada usia ini bayi sudah mendapat berbagai jenis makanan termasuk makanan orang dewasa, sehingga lebih sensitif terkena penyakit.

Berdasarkan hasil penelitian ini, bayi yang menderita diare sebagian besar berjenis kelamin laki-laki. Pada sebagian penelitian menyebutkan bahwa jenis kelamin laki-laki lebih rentan terkena penyakit, karena dianggap lebih aktif daripada perempuan, namun pada sebagian penelitian lain proporsinya sama untuk kedua jenis kelamin.

Berdasarkan hasil penelitian diketahui bahwa faktor risiko kejadian Gastroenteritis banyak terjadi pada kelompok kasus dengan praktik pemberian makan tidak baik sebesar $37(78,7 \%)$ responden, dibandingkan pada kelompok kontrol sebanyak 18 $(38,3 \%)$ responden. Responden dengan praktik pemberian makan tidak baik ini, pada penderita Gastroenteritis yang tidak mendapat ASI Eksklusif sebanyak 20 $(42,6 \%)$ responden dan pada kelompok yang tidak menderita Gastroenteritis sebanyak 10 $(21,3 \%)$ responden.

Pendidikan ibu diduga berkaitan dengan pola asuh pemberian makan ibu, dimana pada bayi yang mengalami Gastroenteritis mayoritas ibu berpendidikan SMA, sementara pada kelompok bayi yang tidak mengalami Gastroenteritis mayoritas ibu dengan tingkat pendidikan yang lebih tinggi (Sarjana). Hal ini sejalan dengan penelitian Marisa, Fajar, \& Ikob (2009) yang menyatakan bahwa tingkat pendidikan ibu berhubungan dengan kejadian diare pada bayi dengan nilai p 0,0001. Pendidikan ibu juga melatarbelakangi pengetahuan, kemauan dan keterampilan ibu dalam praktik pemberian makan bayi yang baik. 
Pada kelompok kasus sebanyak 57,4\% bayi yang mendapat ASI Eksklusif sedang pada kelompok kontrol terdapat $78,7 \%$ yang mendapat ASI Eksklusif. Hal ini tentunya akan memengaruhi daya tahan tubuh bayi sehingga lebih rentan mengalami Gastroenteritis. Begum (2013) juga menyatakan bahwa bayi yang mendapat cukup nutrisi terutama yang berasal dari ASI akan lebih jarang terkena penyakit yang berhubungan dengan saluran cerna seperti Gastroenteritis dengan nilai OR 0,001. Penelitian Rahmadhani (2013) menemukan bahwa ada hubungan yang bermakna antara pemberian ASI Eksklusif terhadap kejadian diare akut pada bayi usia 0-1 tahun di Puskesmas Kuranji Kota Padang dengan nilai $p$ sebesar 0,001 .

Praktik pemberian makan yang tidak baik ditemukan pada penelitian ini adalah bayi tidak mendapat kolostrum segera setelah lahir. Seperti yang telah diketahui bahwa kolostrum adalah ASI yang keluar pada hari pertama setelah bayi lahir dan berwarna agak kekuningan serta mengandung karbohidrat, protein dan antiboodi (IgG). Kolostrum mensuplai berbagai faktor kekebalan dan faktor pertumbuhan pendukung kehidupan dengan kombinasi zat gizi yang sempurna untuk menjamin kelangsungan hidup, pertumbuhan dan kesehatan bayi baru lahir. Hal ini sesuai dengan penelitian Sazali, dkk (2009) yang menyatakan kolostrum dalam ASI meningkatkan dampak proteksi terhadap berbagai macam infeksi pada bayi. Namun demikian, tidak semua bayi beruntung mendapatkan kolostrum di awal masa kehidupannya. Banyak alasan yang dikemukan ibu mengapa tidak memberikan kolostrum kepada bayi, diantaranya adalah ASI tidak keluar, tidak tahu, anggapan bahwa kolostrum adalah susu basi adalah yang paling dominan pada penelitian ini.

Pemberian makanan yang terlebih dahulu dikunyah oleh ibu (meme) menjadi salah satu penyebab praktik pemberian makan yang tidak baik pada penelitian ini. Makanan yang bersih dan higienis adalah syarat makanan sehat dan layak dikonsumsi. Masa bayi merupakan masa rawan dimana tubuh belum mampu menghasilkan antibodi secara sempurna dan usus juga belum mampu mencerna seperti orang dewasa. Dengan mengkonsumsi makanan yang terlebih dahulu dikunyah oleh ibu akan berpotensi menambah bakteri yang tidak baik pada makanan yang akan diberikan kepada bayi, terlepas dari kondisi kesehatan mulut dan gigi ibu tersebut (Berek, Faizah, \& Purwaningsih, 2008). Hal ini akan meningkatkan risiko bayi makan makanan yang terkontaminasi bakteri dan menyebabkan gangguan pada saluran cerna yang dapat menimbulkan Gastroenteritis pada bayi (Berek, Faizah, \& Purwaningsih, 2008). Hasil penelitian ini senada dengan penelitian Amaliah (2010) yang menyatakan ada hubungan yang signifikan antara faktor budaya mengunyahkan makanan sebelum diberikan pada anak terhadap kejadian diare pada balita di Kabupaten Sukoharjo dengan nilai $p<0,005$.

Perilaku mengunyah makanan sebelum diberikan kepada bayi ini dipengaruhi oleh budaya turun temurun dan kebiasaan masyarakat setempat. Bila ibu bayi masih tinggal serumah dengan mertua atau orangtua, maka praktik ini paling sering dilakukan. Kebiasaan ini dipengaruhi oleh filosofi budaya setempat yang beranggapan bahwa tokoh sentral dalam keluarga adalah perempuan/ibu yang mempunya tiga tugas yaitu parmeme, panuturi dan parorot. Parmeme artinya yang mengunyahkan makanan untuk diberikan kepada anak kecil/ bayi.

Penelitian Lamberti, dkk (2011) dalam Begum (2014) di Afrika Selatan tahun 2001 menemukan bahwa lebih dari dua pertiga ibu dan pengasuh yang mengunyahkan 
makanan untuk bayi mereka menyebabkan bayi-bayi berisiko tertular HIV jika ibu atau pengasuhnya juga HIV positif. Dalam penelitian terungkap, para ibu atau pengasuh yang sedang menderita masalah gusi berdarah dan sariawan juga menyebabkan adanya darah yang terbawa pada makanan yang dikunyahkan terlebih dahulu sehingga menjadi jalan penularan, apalagi jika anak sedang dalam fase tumbuh gigi atau ada luka di mulutnya. Lamberti, dkk (2001) menjelaskan bahwa hasil penelitian ini bisa menjelaskan perlunya menghentikan kebiasaan melunakkan makanan dengan mulut ibu sebelum diberikan pada bayi.

Hal lain yang berpotensi buruk pada praktik pemberian makan bayi adalah tidak memasak air minum yang digunakan untuk bayi sampai mendidih. Alasan yang dikemukakan adalah bahwa beberapa desa di wilayah kerja Puskesmas Silangit tidak memiliki sumber air minum yang layak. Masyarakat mengandalkan hujan sebagai sumber air untuk kebutuhan sehari-hari. Berdasarkan profil kesehatan Kabupaten Tapanuli Utara tahun 2016 terdapat 3.100 masyarakat di wilayah kerja Puskesmas Silangit menggunakan air hujan sebagai sarana air bersih (Dinas Kesehatan Tapanuli Utara, 2016). Berdasarkan profil tersebut angka kejadian diare menempati peringkat kelima dari 21 jenis penyakit terbanyak. Pada musim kemarau masyarakat akan kesulitan untuk mendapat air bersih. Sebagai alternatif masyarakat menggunakan jasa isi ulang air minum kemasan galon yang diolah oleh penduduk setempat. Air isi ulang tersebut diyakini masyarakat sudah bersih dan layak minum, sehingga cukup dihangatkan saja tanpa direbus sampai mendidih. Hal ini meningkatkan risiko bayi terkontaminasi air minum yang mengandung bakteri yang dapat mengakibatkan diare. Amaliah (2010) menyatakan ada hubungan yang bermakna antara air minum direbus terhadap kejadian diare pada anak balita di Kabupaten Sukoharjo ( $p$ 0,001).

Pada penelitian ini sebagian besar responden yang mengalami Gastroenteritis berasal dari wilayah yang sarana air bersihnya berasal dari air hujan, sedangkan untuk responden yang tidak mengalami Gastroenteritis hanya sebagian kecil saja yang menggunakan air hujan sebagai sarana air bersih.

Pemberian makan dengan dikunyah (meme), pemberian air minum yang tidak direbus menjadi penyebab praktik pemberian makan ibu kepada bayi menjadi tidak baik. Banyak faktor yang menjadi latar belakang terjadinya masalah tesebut. Kebiasaan yang turun temurun dari orangtua, lingkungan, pengetahuan, tingkat pendidikan ibu, pekerjaan dan keadaan sosial ekonomi menjadi penyebabnya. Perbaikan praktik pemberian makan bayi menjadi baik diharapkan dapat menurunkan angka kejadian Gastroenteritis pada bayi. Pemberian ASI Eksklusif dan kolostrum pada bayi juga dapat menjadi solusi perbaikan praktik pemberian makan pada bayi. Banyak manfaat yang dapat diperoleh dari pemberian ASI dibanding susu formula. Selain higienis, ASI juga praktis dan ekonomis dibandingkan dengan susu formula. Risiko bayi menderita gangguan saluran cerna seperti gastroenteritis juga meningkat bila bayi mendapat susu formula. Hal ini sesuai dengan penelitian Sazali, dkk (2009) yang menyatakan bahwa bayi yang diberi ASI Eksklusif lebih jarang terkena diare dibandingkan dengan yang diberi susu formula dengan nilai OR sebesar 3,325.

\section{SIMPULAN}

Praktik pemberian makan ibu pada bayi yang mengalami Gastroenteritis mayoritas tidak baik. Bayi akan memiliki risiko 8,2 kali lebih besar mengalami gastroenteritis jika praktik pemberian makan tidak baik. Bagi 
masyarakat di wilayah kerja Puskesmas Silangit khususnya bagi ibu yang memiliki bayi disarankan agar merubah praktik pemberian makan melalui pemberian ASI Eksklusif, kolostrum kepada bayi, berperilaku hidup bersih, membawa bayi untuk diimunisasi segera setelah lahir dan melengkapi perolehan imunisasi bayi sebelum berumur 1 tahun. Bagi Puskesmas Silangit agar lebih meningkatkan penyuluhan kesehatan tentang pencegahan Gastroenteritis kepada ibu yang memiliki bayi, perlunya imunisasi dan ASI Eksklusif melalui kunjungan rumah setiap bulannya sehingga bayi terhindar dari berbagai macam penyakit infeksi.

\section{DAFTAR PUSTAKA}

Amaliah, S. (2010). Hubungan sanitasi lingkungan dan faktor budaya dengan kejadian diare pada anak balita di desa Toriyo Kabupaten Sukoharjo. Prosiding Seminar Nasional Unimus.

Begum, M. U. H. (2013). Breast Feeding versus Formula Feeding and Diarrheal Diseases in Infant nd Children - $A$ Review. Pediatric International: Bangladesh, 32: 26-30.

Berek, T., Faizah, Z., Purwaningsih, E. (2008). Pola Asuh Ibu, Kejadian Diare dan Pertumbuhan sampai 4 bulan pada Bayi yang mengalami Hambatan Pertumbuhan Dalam Rahim. Jurnal Media Medika Indonesia, 43(3): 122-129.
Dinas Kesehatan Tapanuli Utara. (2016). Profil Kesehatan Kabupaten Tapanuli Utara Tahun 2015. Tarutung: Dinkes Tapanuli Utara.

Khairuniyah. (2012). Pemberian ASI Ekslusif ditinjau dari Faktor Motivasi, Persepsi, Emosi dan Sikap pada Ibu yang Melahirkan (Tesis). Universitas Padjajaran, Bandung, Indonesia.

Lamberti, L., Walker, C., Victora, C., Black, R. (2011). Breastfeeding and the risk for diarrhea morbidity and mortality. BMC Public Health (Suppl 3): S15.

Marisa, A., Fajar, N. A., Ikob, R. (2009). Faktor-faktor yang berhubungan dengan kejadian diare pada anak usia 6-24 bulan di wilayah kerja puskesmas swakelola Kota Palembang. Jurnal IImu Kesehatan Masyarakat, 1(2): 128-133.

Sazali, O., Lubis, B. M., Sianturi, P., Azlin, E., Cipta, G. D. (2009). Dampak proteksi air susu ibu terhadap infeksi. Jurnal Sari Pediatri, 11(3): 167-173.

Yanthi, E. (2001). Analisis Faktor Resiko Terhadap Kejadian Diare di Kecamatan Padang Bolak Julu Kabupaten Tapanuli Selatan Tahun 2001 (Tesis). Program Pasca Sarjana Universitas Sumatera Utara, Medan, Indonesia. 